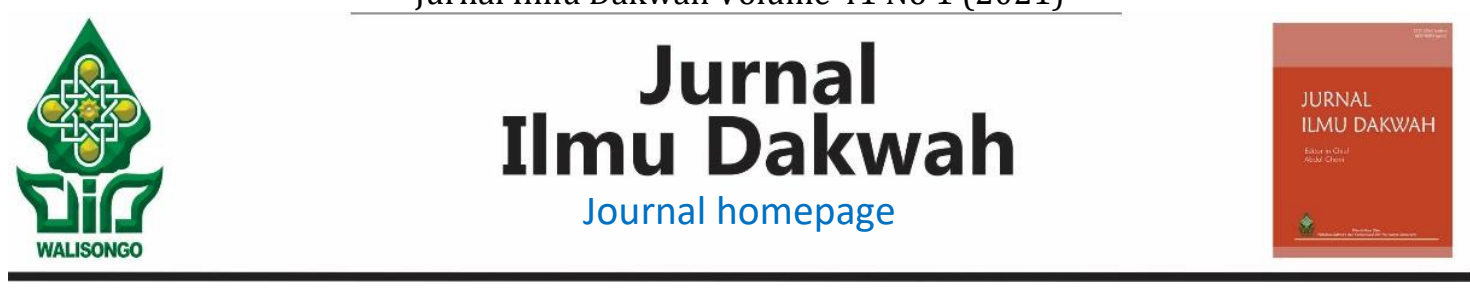

\title{
Dakwah Islam dan pencegahan radikalisme melalui ketahanan masyarakat
}

\author{
Najahan Musyafak ${ }^{1}$, Lulu Choirun Nisa ${ }^{2}$ \\ 1,2 Universitas Islam Negeri Walisongo Semarang \\ 1Email:nmusyafak@yahoo.com \\ 2Email: lulu.choirunnisa@walisongo.ac.id
}

\begin{abstract}
Community resilience is an important aspect of da'wah as an effort to prevent radicalism in Indonesia. The importance of community resilience is based on the phenomenon where the community has become the victim of various events that have the nuances of radicalism. Bombings, shootings, stabbings and vandalism events have harmed the community, both individually and collectively. The destruction of public facilities has disrupted social activities and governance. In addition, violent-motivated events have disrupted people's lives because they feel afraid, insecure, and threatened by circumstances that are beyond their capabilities. Therefore, it is necessary to have da'wah through efforts of resilience in the face of acts of violence with a background of radicalism. This study aims to determine da'wah activities through the form of community resilience by taking locations in the Solo Raya area in the face of various radicalism events, forms of community resilience and how steps are taken to prevent the spread of radical ideology through da'wah activities. This study is a qualitative research with a symbolic interactionism approach involving a number of informants who were selected using a purposive sampling method from 4 areas in Solo Raya, namely Surakarta, Sukoharjo, Sragen and Karanganyar. Data was collected through a Focus Group Discussion technique ( FGD). This study found that Da'wah can be utilised as a method to prevent radicalism through strengthening community resilience. The way of prevention focus on anticipating and adapting to the dangers of radicalism through 4 (four) forms; awareness of plurality, synergy between institutions, cultural communication and strategic partnerships.
\end{abstract}

Keywords: Radicalism, da'wah, resiliency, and prevention.

\begin{abstract}
Abstrak
Ketahanan masyarakat (Community Resiliency) menjadi aspek penting dalam dakwah sebagai upaya pencegahan radikalisme di Indonesia. Pentingnya ketahanan masyarakat didasarkan pada fenomena dimana masyarakat telah menjadi korban berbagai peristiwa yang bernuansa radikalisme. Peristiwa pengeboman, penembakan, penusukan dan perusakan telah merugikan masyarakat baik secara individu maupun komunitas. Hancurnya fasilitas publik telah menggangu kegiatan dan tata laksana sosial. Selain itu, peristiwa bermotif kekerasan telah mengganggu kehidupan masyarakat karena merasa takut, tidak aman, dan terancam oleh keadaan yang berada di luar kemampuan mereka.
\end{abstract}


Oleh karena itu, dibutuhkan adanya dakwah melalui upaya ketangguhan (resiliency) dalam menghadapi tindakan kekerasan yang berlatarbelakang radikalisme. Studi ini bertujuan untuk mengetahui kegiatan dakwah melalui bentuk ketahanan masyarakat dengan mengambil lokasi di wilayah Solo Raya dalam menghadapi berbagai peristiwa radikalisme, bentuk ketangguhan masyarakat dan bagaimana langkah yang ditempuh untuk melakukan pencegahan terhadap penyebaran ideologi radikal melalui kegiatan dakwah. Studi ini merupakan penelitian kualitatif dengan pendekatan interaksionisme simbolik dengan melibatkan sejumlah informan yang dipilih dengan metode sampel bertujuan (purposive sampling) yang berasal dari 4 wilayah di Solo Raya, yaitu Surakarta, Sukoharjo, Sragen dan Karanganyar, dan data diambil melalui teknik Focus Group Discussion (FGD). Studi ini menemukan bahwa dakwah pencegahan radikalisme dapat dilakukan melalui penguatan ketahanan masyarakat yang merupakan proses antisipasi dan adaptasi terhadap bahaya atau bencana radikalisme melalui 4 (empat) bentuk; kesadaran pluralitas, sinergitas antar lembaga, komunikasi budaya dan kemitraan strategis.

Kata Kunci: Radikalisme, dakwah, resiliensi, dan pencegahan.

\section{PENDAHULUAN}

Radikalisme merupakan persoalan bangsa yang membutuhkan partisipasi masyarakat dalam proses pencegahannya. Persitiwa radikal sebagaimana terjadi dalam wujud pengeboman, penembakan, penusukan dan perusakan secara langsung maupun tidak langsung telah merugikan publik, baik secara individu maupun komunitas. Selain menyebabkan rusaknya fasilitas publik dan menggangu kegiatan dan tata laksana sosial serta masyarakat, peristiwa yang melibatkan aksi kekerasan telah mengganggu kehidupan individu berupa perasaan takut, tidak aman, trauma dan merasa terancam oleh keadaan yang berada di luar kemampuan dirinya. Kejadian yang berlangsung secara terus menerus dan berulang bisa menyebabkan ketidakberdayaan masyarakat dalam mengelola tata kehidupan dalam lingkup personal dan komunal. Ketidakberdayaan masyarakat tercermin dari tidak berlakunya sistem keamanan sosial dalam menjaga ketertiban dan keamanan lingkungan. Masyarakat tidak mampu lagi mendeteksi dan mengetahui hadirnya ancaman yang datang di lingkungannya. Dalam waktu yang bersamaan, masyarakat menjadi apatis dan tidak peduli terhadap peristiwa yang menimpa. Masyarakat menganggap bahwa peristiwa yang menerpa wilayah sekitarnya sudah menjadi hal yang lumrah dan tidak perlu dikhawatirkan. Dampak yang diakibatkan oleh berbagai peritiswa radikalisme telah merugikan secara personal dan struktural yang ditandai dengan melemahnya tingkat ketangguhan atau ketahanan masyarakat.

Resiliensi dipahami sebagai suatu kemampuan individu dan komunitas dalam menahan atau menetralkan efek langsung dari kekuatan penekan dari luar sehingga tidak terjadi ketidakfungsian peran dan pada gilirannya mampu menyesuaikan dengan lingkungan yang berubah (Pimm, 1984; Gunderson dan Holling, 2001). Ketahanan juga merupakan sebuah proses untuk beradaptasi dengan baik dalam menghadapi kesulitan, trauma, tragedi, atau bahkan sumber stres berat (Masten, 2001). Sebagaimana ditunjukkan oleh Pimm (1984) bahwa resiliensi merupakan kemampuan sistem sosial untuk melawan adanya gangguan dan mampu untuk kembali kepada situasi keseimbangan setelah terjadinya gangguan. Dengan demikian, resiliensi tidak hanya terkait dengan kemampuan individu dan masyarakat untuk menghadapi tekanan dari luar, tetapi juga berkaitan pada 
sejauhmana kemampuan adaptif mereka terhadap lingkungan yang berubah. Resiliensi ini dibutuhkan dalam dakwah, sebagai bagian dari bentuk amar ma'ruf dan nahyu 'an al munkar di tengah-tengah situasi ancaman dari dampak yang diakibatkan oleh radikalisme.

Perubahan lingkungan sebagai akibat dari peristiwa yang terjadi pada suatu komunitas tidak hanya memiliki implikasi juga terhadap kehidupan ekonomi, sosial, agama, budaya, keamanan dan keselamatan individu, masyarakat bahkan negara. Secara sosiologis, aksi teror yang dilakukan oleh sekelompok orang telah mengganggu dan merusak struktur sosial kemasyarakatan, renggangnya hubungan antar individu dan masyarakat, dan terhambatnya aktifitas sosial ekonomi yang merupakan penggerak roda kehidupan. Sedangkan secara psikologis, peristiwa kekerasan yang terjadi secara mendadak mengakibatkan masyarakat mengalami shock, takut dan pada suatu waktu tertentu bisa mengalami trauma. Terlebih bagi mereka yang secara langsung mengalami peristiwa tersebut.

Kajian tentang resiliensi pada awalnya fokus pada kemampuan masyarakat dalam menghadapi perang, bencana alam, tragedi, teror dan kecelakaan (Kindt, 2006; Stevan Weine \& Osman Ahmed, 2012; Yusup, 2016; Ellis \& Abdi, 2017). Kindt (2006) menegaskan bahwa resiliensi di kalangan militer dapat ditempuh melalui dua jalur yaitu menyebarkan informasi kepada pemerintah federal, negara bagian, dan lokal mengenai risiko tindakan teroris secara komprehensif dan efektif; dan kedua adalah memperkuat setiap individu melalui pendidikan, pelatihan, dan layanan sukarela agar masyarakat merasa lebih aman, lebih kuat, dan lebih siap dalam menghadapi ancaman. Sementara itu, resiliensi komunitas rawan bencana sebagaimana ditunjukkan oleh Yusup (2016) diwujudkan dengan kemampuannya dalam menganalisis faktor-faktor mendorong komunitas memilih hidup bersama risiko bencana dan bagaimana mereka mengkonstruksi ruang untuk hidup bersama risiko dalam konteks ekonomi-politik, budaya dan ekologi, serta bahaya yang berubah dari waktu ke waktu.

Sejalan dengan hal ini, kajian yang Mushtaq (2009)Ellis \& Abdi (2017) mengeksplorasi tentang pemanfaatkan aset masyarakat untuk mencegah ekstremisme kekerasan bagi pemuda dan model ketahanan masyarakat dalam kesiapsiagaan bencana. Studi ini menunjukkan bahwa hubungan sosial adalah inti dari ketangguhan komunitas sehingga hubungan sosial perlu ditingkatkan, di pihak lain diperlukan upaya untuk mempertahankan peran yang dimiliki. Kajian lain yang relevan adalah apa yang dilakukan oleh Weine dan Ahmed (2012) yang merekomendasikan perlunya meningkatkan ketahanan masyarakat dengan penguatan sumber daya pelindung melalui pengurangan peluang yang ada. Dari berbagai kajian tersebut terlihat belum banyak studi yang membahas konseptualisasi ketahanan masyarakat sebagai bagian dari upaya dakwah dalam pencegahan radikalisme di Indonesia. Dengan demikian studi ini menempatkan ketahanan masyarakat selain sebagai alternatif dalam pencegahan radikalisme, juga merupakan modal sosial yang memungkinkan keberlanjutan program deradikalisasi dengan menggunakan pendekatan agama.

\section{METODE}

Penelitian ini merupakan penelitian kualitatif dengan pendekatan interaksionisme simbolik. Pendekatan ini dipilih karena penelitian kualitatif bertujuan untuk mendapatkan pemahaman yang mendalam tentang sebuah peristiwa dan menyediakan penjelasan yang 
tersirat mengenai struktur, tatanan dan pola yang luas dalam suatu kelompok (Denzin dan Lincoln, 1994). Penelitian kualitatif juga digunakan untuk memahami masalah manusia dalam konteks sosial dengan menciptakan gambaran menyeluruh dan kompleks, menyajikan pandangan terperinci dari para sumber informasi dalam setting yang alami (Creswell, 2014). Karakteristik tersebut selaras dengan tujuan penelitian ini.

Informan (narasumber) penelitian adalah seseorang yang memiliki informasi tentang objek penelitian. Informan dalam penelitian ini adalah orang yang diwawancara langsung yang disebut sebagai narasumber dan mengikuti Focus Group Discussion (FGD) yang dilakukan dalam teknik pengambilan data. Penentuan informan menggunakan teknik purposive sampling, yaitu teknik pengambilan sampel sebagai sumber data dengan pertimbangan tertentu (Sugiyono, 2010:300). Pertimbangan tertentu ini antara lain orang tersebut dianggap memahami tentang apa yang peneliti harapkan, sebagai penentu kebijakan, tokoh agama, tokoh masyarakat sehingga memudahkan untuk menjelajahi objek/situasi sosial yang diteliti, (Sugiyono, 2012:54). Peneliti beralasan bahwa teknik ini mampu mengumpulkan data yang benar-benar real atau nyata dengan mewawancarai informan yang mengetahui atau menguasai suatu keahlian atau pekerjaan tertentu di bidangnya guna mempermudah pengolahan data untuk keperluan penelitian.

Jumlah informan dalam studi ini adalah 56 orang yang tersebar di empat (4) Kabupaten/ Kota yang sudah ditentukan dengan menggunakan teknik sampel bertujuan. Komposisi informan memiliki latar belakang sosial yang beragam terdiri dari perwakilan dari Kesbangpol Linmas, Kepolisian, Kementerian Agama, tokoh agama, tokoh masyarakat, tokoh pemuda, akademisi, guru SMA/ SMK/MA, tokoh perempuan, dan penyuluh agama. Selain pertimbangan latar belakang sosial, pemilihan informan juga berdasarkan pada pertimbangan aspek gender dalam rangka memperoleh perspektif yang seimbang dan komprehensif dalam menilai sebuah peristiwa serta untuk menghindari terjadinya bias gender (Faqih, 2008). Informan yang mengikuti kegiatan Focus Group Discussion (FGD) sebanyak 42 laki-laki dan 14 perempuan.

Penelitian ini mengambil lokasi kajian di wilayah Solo Raya yang terdiri dari tujuh daerah, yaitu satu Kota dan enam Kabupaten, yaitu Kota Surakarta, Kabupaten Sukoharjo, Kabupaten Karanganyar, Kabupaten Sragen, Kabupaten Boyololi, Kabupaten Klaten dan Kabupaten Wonogiri, Selanjutnya, berdasarkan pertimbangan tujuan penelitian, intensitas peristiwa yang terjadi dan tingkat aksesbilitas terhadap informan serta waktu penelitian, maka studi ini memilih 4 daerah yaitu Kota Surakarta, Kab, Sukoharjo, Kab, Karanganyar dan Kabupaten Sragen.

Data dikumpulkan melalui teknik dokumentasi, wawancara dan diskusi grup yang terfokus atau Focus Group Discussion dalam rangka memperoleh data yang dibutuhkan baik yang bersifat primer dan sekunder. Tujuan FGD adalah untuk mengeksplorasi masalah yang spesifik, yang berkaitan dengan topik yang dibahas. Teknik ini digunakan dengan tujuan untuk menghindari pemaknaan yang salah dari peneliti terhadap masalah yang diteliti. FGD digunakan untuk menarik kesimpulan terhadap makna-makna intersubjektif yang sulit diberi makna sendiri oleh peneliti karena dihalangi oleh dorongan subjektivitas peneliti (Creswell, 2014; Sugiyono, 2010). 


\section{HASIL DAN DISKUSI}

Radikalisme yang mengarah kepada kekerasan sosial keagamaan di Solo Raya secara umum disebabkan oleh empat faktor, yaitu: faktor rasial, politik, ekonomi, dan faktor segregasi social. Konflik rasial terjadi di Surakarta antara laintawuran kongsing Cina-Jawa pada tahun 1911, konflik pribumi (abang becak) dengan etnis Arab pada tahun 1972, dan konflik pemuda Tionghoa dengan Jawa pada September 1980 (Mulyadi, 2012: 46).

Konflik sosial lain yang muncul ke permukaan yakni adanya pengaruh dari situasi politik makro di Indonesia pada tahun 1911 yaitu terjadinya peristiwa Sarikat Islam, revolusi sosial anti Swapraja tahun 1946, peralihan kekuasaan dari Orde Lama (Soekarno) ke Orde Baru (Soeharto) pada tahun 1965, dan kerusuhan reformasi tahun 1998, Sedangkan yang bersifat mikro (regional) di antaranya adalah benturan konsep Vorst Domain vs Volks Domain yang berakibat munculnya Sarekat Hindia tahun 1919 dalam kasus H, Misbach, lahirnya pemogokan buruh kereta api tahun 1924, dan pergeseran konsep projo kejawen menuju konsep kolonial dan modern yang mengakibatkan terjadinya revolusi sosial tahun 1946.

Sederetan peristiwa kekerasan sosial di Solo sampai tahun 1998 atau dapat disebut pra reformasi disebabkan secara dominan oleh kepentingan politik, ekonomi dan budaya. Telah terjadi pergeseran latar belakang dan motif munculnya konflik sosial di Solo Raya pasca reformasi, yaitu masuknya aspek agama sebagai pemantik (trigger) ketidakstabilan situasi sosial di masyarakat, Oleh karena itu diperlukan adanya upaya yang sistematis, terukur dan berkelanjutan yang dapat menciptakan kestabilitasan social melalui peningkatan imunitas atau kekebalan sebagai modal untuk membangun masyarakat yang kuat.

Perlu adanya upaya dakwah pencegahan (nahyu 'an al munkar) dalam rangka antisipasi pada dampak yang ditimbulkan oleh radikalisme. Kesadaran akan pentingnya langkah antisipatif dari masyarakat Solo Raya telah mengemuka dan menjadi wacana dalam berbagai forum pertemuan antar tokoh masyarakat, pejabat dan organisasi sosial keagamaan. Masyarakat perlu mengidentifikasi dan mengetahui adanya potensi tindak kekerasan sosial keagamaan, termasuk radikalisme agama yang bersifat rasial dan laten. Oleh karena itu diperlukan tindakan yang bisa memperkuat tatanan sosial kemasyarakatan melalui ketahanan masyarakat (community resilience), meminimalisasi adanya ketimpangan ekonomi sehingga tidak terjadi kelas juragan dan kelas pembantu (budak), dan memahami akar kerusuhan yang bersifat local genus.

\subsection{Dakwah Pencegahan}

Dakwah merupakan upaya mengajak atau menyeru ke arah kebaikan dan dalam waktu yang sama merupakan upaya nahyu 'anil munkar, atau mencegah perbuatan munkar. Penegasan tersebut terlihat dalam Al-Qur'an surat Ali Imron ayat 104. Ayat tersebut sebagimana ditegaskan Muhyiddin (2002: 44) mengandung tiga perintah suci bagi kehidupan sosial kemasyarakatan, yaitu seruan kepada khair, anjuran untuk berbuat ma'ruf, dan pencegahan dari yang munkar. Istilah amar ma'ruf nahi munkar merupakan istilah yang utuh dan tidak dipisahkan. Kesatuan konsep ini tersebut sebanyak 9 kali dalam 5 surat di dalam Al-Qur'an. Dakwah dengan cara amar ma'ruf diyakini lebih ringan daripada 
dakwah nahi munkar. Dakwah amar ma'ruf berkaitan dengan yang dikenal, dimengerti, dipahami, dan diterima oleh masyarakat, sementara nahi munkar, dipahami sebagai realitas sosial yang dibenci, tidak disenangi, ditolak karena dianggap tidak patut, tidak pantas, serta tidak seharusnya dilakukan oleh manusia berakal.

Pencegahan terhadap hal-hal yang tidak baik perlu dijalankan untuk kegiatan dakwah termasuk di dalamnya adalah perilaku radikal. Perilaku radikal dalam konteks ini adalah segala tindakan yang yang mengarah kepada kerusakan, pemaksaan kehendak, merasa benar terhadap pendapatnya dan membuat orang lain mengalami ketakutan. Fenomena radikalisme ini perlu mendapatkan sentuhan dakwah pencegahan agar segala hal tidak baik yang berasal dari radikalisme tidak terjadi di masyarakat (Karim dkk, 2021).

\subsection{Kesadaran Pluralitas}

Masyarakat Solo Raya dalam membangun ketahanan masyarakat (community resilience) untuk menangkal radikalisme agama paling tidak dilakukan dengan dua hal: pertama, penguatan civil society sebagai counter gerakan dan wacana radikalisme agama; dan kedua, ketahanan budaya (cultural resilience), Hal tersebut tercermin dari berbagai radikalisme dan kekerasan atas nama agama yang terjadi di Surakarta telah mendorong masyarakatnya mengalami perubahan ke arah positif, yakni adanya kesadaran pluralitas (plurality awareness) yang bisa meminimalisir adanya tindakan radikalisme agama,

Sebagai kekuatan masyarakat sipil, kedewasaan masyarakat Surakarta dalam menghadapi pluralitas dapat dilihat dari kemampuannya membentuk simpul-simpul sosial keagamaan sebagai bentuk kesadaran pluralitas dan penguatan ketahanan sosial budaya sipil (civic culture), Hal tersebut dilakukan sebagai media untuk perekat kehidupan yang damai di tengah pluralitas masyarakat Solo Raya, Munculnya gerakan keagamaan mainstream di ruang publik yang aktif mengampanyekan Islam rahmatan lil'alamin sebagai bentuk penangkalan terhadap radikalisme keagamaan di wilayah ini, Selain gerakan keagamaan mainstream yang dilakukan oleh organisasi keagamaan yang sudah ada seperti NU, di Solo Raya bermunculan fenomena kebangkitan gerakan keagamaan dengan corak sufisme seperti Jamaah Muji Rosul (JAMURO), Jampi Sanubari, Ar-Raudhah, Tali Jiwa, Jamuri, Ahbabul Musthofa, dan Hubbun Nabi,

Kelompok-kelompok tersebut umumnya lahir dari respon terhadap kekerasan agama yang ditampilkan oleh kelompok anti-dialogis seperti kelompok Islamisme bercorak salafi-haraki yang mempunyai pengaruh signifikan terhadap gerakan Islam radikal di Solo Raya, seperti Pesantren Al-Mukmin Ngruki, Pesantren Darul Syahadah, dan Pesantren Isy Karima Karanganyar. Pesantren di atas menjadi pusat harakah dari berbagai pesantren yang ada di daerah sekitarnya, seperti Pesantren Ulil Albab dan Darul Hijrah Sukoharjo, Yayasan Al-Madinah, MMI, JAT, JAK, JAD, Jama'ah Al-Islam Gumuk, Yayasan Al-Baniy Matesih, Yayasan Al-Manar, YAPI Wonosari, Al-Istiqlal, dan Ibnu Abbas Klaten serta beberapa gerakan keagamaan yang bercorak radikal.

Di sisi lain, gejolak fanatisme atas nama agama di Surakarta mulai muncul ke permukaan, yang bisa dilihat dari beberapa kasus antara lain: kota Surakarta memiliki stigma sebagai kota yang melahirkan teroris. Stigma tersebut bisa dirunut pada hampir setiap isu teroris yang mengemuka bisa dipastikan ada warga Solo Raya yang menjadi aktor tersangkanya. Misalnya pada tanggal 16-17 September 2009 di Mojosongo, Solo, Jawa Tengah, empat tersangka teroris yang paling dicari tewas oleh Densus 88 Antiteror. 
Keempat, tersangka adalah Noordin M, Top, Bagus Budi Pranoto alias Urwah, Adit Susilo alias Hadi, dan Aryo Sudarso alias Aji. Pada tahun Mei 2010 juga ditangkap 5 orang yang diduga kuat sebagai jaringan teroris (Purwawidada, 2014). Kedua, kota Surakarta memiliki tingkat konflik keberagamaan yang berujung pada pelanggaran terhadap kebebasan beragama.

Keberadaan gerakan keagamaan mainstream di Solo Raya yang bercorak moderat mengusung pola keberagamaan humanis yakni wajah Islam terlepas dari nuansa fanatisme dan ekskluvisme yang menjadi pemicu radikalisme agama. Keberadaan kelompok keagamaan mainstream ini selain sebagai counter narasi dan gerakan sekaligus menjadi kekuatan civil society yang menjadi basis massa dalam menguatkan pola keberagamaan masyarakat Solo Raya sekaligus sebagai alternatif sufistik berupa praktik keberagamaan yang inklusif, toleran, dan menekankan keterbukaan di tengah masyarakat multicultural.

Implementasi praktik keberagamaan yang diusung kelompok mainstream ini berbasis pada wacana multikulturalisme tersebut sangat dibutuhkan untuk meningkatkan kesadaran saling menghargai, menghormati, dan toleransi untuk menghindari adanya kekerasan atas nama agama dan ancaman diintegrasi masyarakat Solo Raya. Kelompok keagamaan mainstream seperti Nahdlatul Ulama (NU), Ahbabul Musthofa, Jamuro, Jamuri, Tali Jiwo, Hubbun Nabi, Ar-Raudhah, dan Jampi Sanubari menjadi media kultural yang efektif karena bersifat terbuka tidak memandang stratifikasi sosial, tidak ada yang diistimewakan. Karena itu, kelompok keagamaan ini menjadi kekuatan civil society untuk melakukan gerakan sosial dengan framing Islam ramah yang menjadi counter narasi radikalisme agama seklaigus menjadi titik kumpul dan alat untuk menanamkan multikulturalisme, perbedaan pandangan keagamaan, madzab, cara keberagamaan, dan upaya menciptakan kehidupan yang harmonis antar elemen yang berbeda di Solo Raya.

\subsection{Sinergitas Kelembagaan sebagai Gerakan Dakwah Komunitas}

Upaya masyarakat Solo Raya dalam gerakan dakwah komunitas dengan cara membangun ketahanan (community resiliency) dilakukan dengan menjaga keutuhan, persatuan dan kesatuan antar elemen yang secara empirik dapat dilihat dari beberapa macam aktifitas dan kegiatan yang dilakukan oleh individu tokoh, kelompok maupun masyarakat yang mencakup sektor agama, pendidikan, sosial dan birokrasi. Respons terhadap munculnya kekerasan di masyarakat dan berbagai peristiwa teror yang secara langsung maupun tidak langsung mengancam keamanan lingkungan, individu dan rasa persatuan telah melahirkan sebuah kesadaran di masyarakat untuk mempertahankan eksistensi kebersamaannya melalui kerjasama lintas agama, organisasi dan golongan sesuai dengan konteks dan kebutuhan. Kerjasama yang dibangun oleh masyarakat Solo Raya sudah berlangsung lama dan biasanya didasarkan pada isu dan situasi yang dihadapi sehingga sifatnya bisa permanen dan atau insidental.

Forum Suara Hati Kebersamaan Bangsa (FSHKB) misalnya, merupakan sebuah wadah bagi para pemimpin agama dari berbagai komunitas di Solo yang lahir untuk mengantisipasi dan mensikapi akibat yang lebih luas setelah peristiwa kerusuhan Mei 1998. Forum yang difasilitatori oleh KH Dian Nafi, pengasuh pondok pesantren Al Muayyad Windan dan sekaligus sebagai anggota, bekerja bersama untuk mencegah meluasnya kejadian konflik dan kekerasan antar komunal. Mereka siaga kapanpun dibutuhkan untuk melakukan kegiatan dan aksi perdamaian (Pohl, 2009). Berbasis di pondok pesantren 
Windan, KH Dian Nafi juga mendirikan Interfide (Institut Dialog Antar Iman) Windan yang tujuannya untuk membangun perdamaian di masyarakat, dialog antar agama serta mempromosikan demokrasi, pluralisme, dan keadilan gender.

Organisasi berbasis institusi lintas agama yang ada di Kota Solo adalah Lembaga Perdamaian Lintas Agama dan Golongan). LPLAG adalah suatu lembaga yang terdiri dari sejumlah tokoh agama dan aktifis perdamaian di Surakarta yang terbentuk dari aspirasi murni masyarakat Surakarta. LPLAG merupakan lembaga nonprofit bersifat independen dan merupakan gerakan berbagai tokoh agama, masyaratkat serta golongan untuk membangun Solo sebagai kota damai. Pada awalnya, lembaga ini berbentuk forum yang secara resmi didirikan pada tanggal 23 Pebruari 2003. Prasetyo (2013) menyatakan bahwa tujuan dari didirikannya forum ini adalah untuk menjaga kondusifitas Kota Surakarta. Seiring dengan dinamika dan kebutuhan organisasi, lembaga ini pada tahun 2019 berubah bentuk menjadi Yayasan Perdamaian Lintas Agama dan Golongan (YPLAG). Tokoh-tokoh agama yang aktif dalam Yayasan ini antara lain Achmad 'Hilmi' Sakdillah dan Al Munawar (Nahdlatul Ulama), Bambang Mulyatno dan Paulus Hartono (Pendeta), Zon Vanel, KH Dian Nafi (Pondok Pesantren) dan Suharso (LDII).

Kegiatan lembaga ini dilakukan secara terencana dan konsisten antara lain mengirimkan peserta pelatihan perdamaian tingkat Asia Pasifik di Mindanao Filipina yang diselenggarakan oleh Mindanao Peacebuilding Institute (MPI), Konferensi Pemuda Nusantara untuk Perdamaian Indonesia, Seminar Perempuan dan Perdamaian Kota serta Pelatihan Perdamaian untuk Institusi Berbasis Agama. Menurut Al Munawar, kondisi sosial politik masyarakat Solo Raya setelah berlangsungnya Pemilu Pemilihan Presiden 2018 semakin mengkawatirkan, sehingga perlu ada uluran tangan dari semua pihak termasuk pemerintah untuk ikut mengurai masalah tersebut pada tingkatan akar rumput.

Sementara itu, upaya untuk membangun perdamaian bagi anak muda dilakukan dengan mendirikan Pusat Studi Agama dan Perdamaian (PSAP) pada tahun 2014 di wilayah Solo. PSAP bertujuan untuk mewujudkan persaudaraan kemanusiaan melalui pemberdayaan masyarakat agar bisa berpartisipasi secara aktif dalam proses pembangunan perdamaian, kesejahteraan, keadilan, demokrasi dan kelestarian lingkungan hidup di kota Surakarta dan sekitarnya (Aijudin, 2017; Kurniasih 2019). Untuk mewujudkan tujuan tersebut PSAP, lembaga PSAP yang dipimpin oleh seorang dosen muda Anas Aijudin menjadikan lembaga sebagai tempat untuk: 1) kajian agama dan filsafat; 2) diskusi pengembangan wacana dalam bidang perdamaian, keadilan, demokrasi, gender, kearifan lokal dan kelestarian lingkungan hidup; 3) pemberdayaan masyarakat lintas agama, suku, dan golongan; 4) pendampingan bagi masyarakat korban konflik sosial dan agama, pelanggaran hak asasi manusia (HAM), dan kerusakan lingkungan hidup.

Langkah yang ditempuh PSAP untuk membuka dialog dan kajian secara akademik dan terbuka tersebut relevan dengan fenomena gerakan radikal yang sudah memasuki dunia kampus, sehingga diperlukan adanya pendekatan ilmiah didasarkan pada fakta empirik dan rasional. Ahmad Syarifudin, mahasiswa IAIN Surakarta jurusan Manajemen Bisnis Syariah yang juga aktifis organisasi Pergerakan Mahasiswa Islam Indonesia (PMII), menyatakan bahwa kampus menjadi ladang untuk pengembangan ideologi transnasional. organisasi HTI (HizbutTahrir Indonesia) masuk ke kampus dengan mendirikan kelompok kajian MUSTANIR di IAIN Surakarta dengan mengedepankan tokoh yang menguasai bidang pendidikan dan bahasa Arab. Masuknya organisasi tersebut karena lembaga pendidikan 
tinggi ini dipandang sebagai institusi agama yang secara simbolik memiliki relasi dengan Islam berupa nama, penampilan dan cara berpakaian mahasiswa dan dosennya. Dengan dibubarkannya organisasi HTI oleh pemerintah bukan berarti ideologi yang diusung untuk mendirikan khilafah di Indonesia sudah selesai, namun perlu ada upaya yang serius dan sistematis dari semua pihak.

“...radikalisme tidak selesai dengan mendemo keberadaan HTI yang tidak sejalan dengan ideologi Pancasila dan dibubarkannya organisasi tersebut oleh pemerintah, namun perlu ada upaya nyata yang dimulai dari deteksi dini terhadap mahasiswa baru untuk mengetahui sejauhmana tingkat pemahaman keagamaan mereka. Sudah ada skenario yang mengawal mahasiswa untuk bergabung dengan Lembaga Dakwah Kampus (LDK) dan organisasi mahasiswa tertentu...dan hal ini disponsori oleh partai tertentu...Oleh karen itu, diperlukan pendekatan akademis dan ideologis untuk memberikan pemahaman yang komprehensif dan referensi kuat tentang Islam. Upaya ini harus melibatkan peran orang tua, keluarga dan masyarakat". (Syarifudin, 4 Juli 2019).

\subsection{Komunikasi Budaya}

Para budayawan Solo Raya mendorong pembangunan kesadaran pluralitas melalui aksi budaya (cultural resilience) seperti wayang kampung untuk mengkomunikasikan seni rekonsiliasi pri dan non-pri, Misalnya dengan lakon fei tsu chen digeber keluar masuk kampung yang selama periode konflik terjadi potret segregasi sosial kampung pribumi dan non-pribumi, Misalnya lakon itu digelar di kampung-kampung sekitar pecinan Solo sehingga memperoleh tanggapan positif untuk mengapresiasikan lakon fei tsu chen sebagai lakon rekonsiliasi perkawinan antara etnik Cina dan Jawa,

Wayang kampung sengaja diproduksi untuk menggelar mobilitas kesenian yang tinggi, dalam pencapaian makna dan tujuan lakon-lakon yang bersifat rekonsiliatif, Karena itu, beberapa tema cerita selalu berorientasi pada nilai perdamaian, Untuk mengakomodasikan nilai-nilai rekonsiliasi itu, lakon yang digelar fei tsu chen di kampung Balong sebagai kampung pecinan Solo bulan Agustus 2000 sangat berhasil untuk mencerminkan pesan perdamaian antar etnik pri bumi dan non-pribumi (Ong Hok Ham 1998),

Komunitas wayang suket dengan menampilkan lakon sebagai bentuk sindiran (satire) wujud dari pemberdayaan masyarakat wong cilik untuk menjaga nilai-nilai rekonsiliasi dengan elit politiknya, Hal ini dikarenakan masyarakat Solo Raya adalah suku Jawa secara pandangan hidup lebih suka untuk menyimpan perasaannya dan tekanan (ngrasani, ngudoroso) dari pada langsung berhadapan (adu arep) untuk menyelesaikan persoalan sosial. Dengan pandangan hidup ini, memungkinkan terjadinya kekerasan atas nama agama atau radikalisme agama. Melalui budaya, masyarakat Solo Raya mengantisipasi adanya konflik dengan berbagai bentuk dan faktor penyebabnya. Mereka memiliki paugeran berupa living tradition Jawa"rukun agawe santoso, crah agawe bubrah" tetapi hal tersebut mendapat tantangan dan ujian dalam mewujudkan masyarakat Solo Raya majemuk, toleran, dan hidup saling berdampingan, Paling tidak, kedepan kehidupan harmonis tersebut akan dihadapkan pada persoalan radikalisme agama dan intoleran kelompok keagamaan Islam yang dewasa ini menjamur di Solo Raya. 
Secara sosiologis, masyarakat Solo Raya sebagaimana ditegaskan Anas Saidi merupakan wilayah yang memberi kesempatan yang terbuka kepada paham apa saja untuk berkembang, Paham fundamentalisme dengan gerakan yang sering berbau kekerasan merasa mendapatkan lahan yang subur untuk dikembangkan. Demikian juga paham sekulerisme yang mengabaikan pentingnya moralitas publik untuk dilestarikan, termasuk dalam mencari keuntungan materi melalui cara-cara yang dianggap melanggar etika publik seperti: perjudian dan pelacuran, dalam banyak hal telah mendapatkan tempat yang paling nyaman di wilayah ini. Di samping itu, Solo Raya merupakan basis kaum abangan yang paling nyata, sekaligus kantong spiritual aliran kebatinan.

Fenomena kekerasan atas nama agama persis seperti permainan politik yang memanfaatkan respons keagamaan menjadi perang sekuler. Meski dengan cukup hati-hati ia melihat sisi lain, yakni kemungkinan adanya perlawanan terhadap upaya menentang globalisme dan modernisme (Jurgensmeyer, 2001). Analisis ini didasarkan atas kesamaan dasar lahirnya masalah sosial yang diintroduksi ke dalam perjuangan agama. Lebih lanjut, Juergensmeyer, ada lima skenario yang dilakukan dan telah diterapkan masing-masing negara untuk mengakhiri radikalisme agama, Pertama, skenario kekuatan yang dilakukan dengan cara mengendalikan aktor-aktir pelaku radikalisme agama dengan jalan kekerasan (violence approach). Kedua, skenario ancaman pembalasan dengan kekerasan yaitu dengan memenjarakan untuk menakut-nakuti aktivis-aktivis keagamaan sehingga mereka raguragu untuk melakukan aksinya. Ketiga, skenario dengan melakukan kompromi/negosiasi dengan para aktivis yang terlibat dalam terorisme. Keempat, skenario pemisahan agama dari politik dan kembali pada landasan-landasan moral dan metafisika, artinya politisasi agama dapat dipecahkan melalui sekularisasi. Model seperti ini justru menimbulkan reaksi keras dari aktivis-aktivis keagamaan radikal yang kadarnya semakin tinggi. Kelima, skenario yang mengharuskan pihak-pihak yang saling bertikai untuk menyerukan adanya saling percaya dan saling menghormati.

\subsection{Kemitraan Strategis}

Berbekal pada pengalaman, masyarakat Solo Raya semakin dewasa dalam memotret realitas radikalisme agama dengan bergantung pada bentuk nature dari radikalisme itu sendiri, Artinya, penguatan narasi dan pendekatan budaya (cultural approach) sebagai model early warning system dalam menangani radikalisme agama dengan pola memandirikan masyarakat dan penguatan ikatan sosial yang selama ini dinilai sudah agak kendor akibat arus modernisasi dengan memperkuat relasi dan jaringan kelembagaan dengan pemerintah, aparat, dan perguruan tinggi. Beberapa program yang dilaksanakan secara kolaboratif dan bersama pemerintah kabupaten/ kota adalah keterlibatan dalam Forum Kerukunan Umat Beragama (FKUB), Badan Kesatuan Bangsa, Politik dan Perlindungan Masyarakat (Kesbangpol Linmas), Kelompok Kerja Penyuluh (Pokjaluh) Kementerian Agama, dan Balai Latihan Kerja (BLK) Kementerian Tenaga Kerja. Kegiatan tersebut bermuara pada konsep mengedepankan jaring keselamatan komunitas (community safety net) yang diwujudkan dalam bentuk kegiatan seperti penguatan baseline data sebagai pondasi menetapkan kebijakan dan merumuskan intervensi program reintegrasi sosial dengan memfasilitasi para aktor radikalisme agama untuk kembali hidup 
normal di tengah masyarakat. Berbagai program dilakukan dengan penguatan ekonomi, pemenuhan hak politik, dan rehabilitasi nama mereka di tengah masyarakat.

Kehadiran pemerintah dengan berbagai programnya di atas ternyata belum mampu menyentuh kalangan generasi milenial yang memang rentan terpapar radikalisme. Pola penyebaran dan pendekatan radikalisme telah mengalami perubahan paradigma (shifting paradigm) komunikasi dari offline ke online berbasis media baru seperti Facebook, WhatsApp, Line, Instagram, dan Skype. Perubahan tersebut kurang diantisipasi dengan cepat oleh pemerintah sehingga generasi muda tidak bisa memperoleh rujukan yang tepat sesuai dengan kebutuhannya. Keprihatinan tersebut diungkapkan oleh seorang pejabat Kesbangpol Linmas Kabupaten Sukoharjo:

“... auto kritik saya kepada pemerintah adalah jangkauan pemerintah tidak sampai kepada bagaimana anak muda berislam melalui sosial media,,,Kita hanya bisa melakukan kegiatan-kegiatan yang sifatnya normatif... " (Ardiyansah, 2019).

Selain itu, masyarakat Solo Raya terlibat aktif terhadap kegiatan yang dinisiasi perguruan tinggi seperti IAIN, UMS, dan UNS yang melakukan respon terhadap realitas social untuk membaca situasi awal terkait dengan radikalisme agama dan akar masalahnya untuk memperkaya analisis pengambil kebijakan. Kegiatan akademik seperti seminar, diskusi publik, lokakarya dan penelitian dilaksanakan dengan melibatkan tokoh masyarakat, perwakilan organisasi keagamaan dan sosial. Aktifitas tersebut dilakukan sebagai penguatan terhadap upaya deradikalisasi. Kampus-kampus tersebut juga melakukan kegiatan deradikalisme agama melalui pengembangan dan kontekstualisasi ajaran agama dengan kondisi lokal seperti pengembangan sikap toleransi, menghormati perbedaan, dan penghargaan terhadap pluralitas. Pandangan ini sudah menjadi platform dan sejalan dengan pemikiran dari aparatur sipil negara (ASN) yang berdinas di Kesbangpol Kabupaten Sukoharjo:

... Pancasila hanya satu-satunya yang bisa menangkal radikalisme, Karena di situ ada ajaran untuk saling berbagi, saling bertoleransi, karena sadar bahwa di Indonesia tidak hanya Muslim tetapi berbagai agama di Indonesia mulai ribuan tahun yang lalu sudah hidup berdampingan, sudah saling kerjasama saling toleransi ...(Ardiyansah, 4 Juli 2019)

Ketahanan budaya untuk deradikalisasi agama di Solo Raya dipahami sebagai gerakan kultural (cultural movement) yang dibangun oleh kelompok civil society mendorong tumbuh dan berkembangnya kemandirian pengetahuan masyarakat (knowledge society) termasuk dalam bidang politik dan agama, Dalam konteks ini, gerakan kultural memberikan batasan pada bentuk etika dan moral politik, Ketahanan budaya ini sebagai upaya menanamkan kesadaran kritis pada masyarakat dengan memposisikan Islam sebagai kekuatan moral (moral force) dalam proses perubahan sosial, Sebab, dengan realitas masyarakat Solo Raya yang plural, kemampuan menemukan titik temu sangat menentukan dalam memberdayakan civil society (Wahid, 1994).

Beberapa strategi civil society dalam membangun ketahanan budaya masyarakat Solo Raya antara lain: pertama, melakukan pemetaan (mapping) atas persoalan politik, keagamaan, dan kebangsaan termasuk penguatan berbagai potensi yang ada di masyarakat sebagai basis dari kekuasaan civil society yang akan dikembangkan. Kedua, menggerakan potensi sosial, politik, dan keagamaan civil society sesuai dengan bidang masing-masing. Ketiga, ke depan semua komponen civil society, masyarakat, dan pemerintah mempunyai kapasitas kemandirian. Fokus ketahanan budaya civil society masyarakat Solo Raya 
diarahkan untuk pengembangan pendidikan keagamaan yang moderat, dakwah yang merangkul, isu-isu kebangsaan, dan penguatan potensi lokal. Hal tersebut dilakukan masyarakat untuk menumbuhkan kesadaran dan kemandirian masyarakat atas dasar penguatan kultur sipil dalam pengembangan karakter dan identitas agama dan kebangsaan. Kandiawan menyatakan:

... Kesbangpol telah banyak melakukan upaya, salah satu upaya pencegahan adalah pemahaman kita terkait dengan wawasan kebangsan. Setiap tahun badan Kesbangpol ini melakukan pendidikan pengamalan empat pilar di masing-masing kecamatan dengan mengundang tokoh masyarakat dan tokoh agama. Tujuan dari kegiatan ini adalah memberikan pemahaman terhadap nilai-nilai Pancasila, UUD 19545, NKRI, dan Bhineka Tunggal Ika (FGD, 5 Juli 2019).

Hal tersebut dilakukan sebagai gerakan menuju masyarakat yang terbuka, dimana kekuatan civil society dan komunitas keagamaan mainstream menggerakan budaya sipil (civic culture) serta mendorong implementasi ajaran agama sebagai faktor pembebas, wujud adari pengejawantahan harmonisasi hubungan antar agama. Jika agama hanya ditafsirkan sebagai bagian dari teosentris dan bersifat tekstual-literalis yang hampa dari ruang dan waktu, maka ketika wacana keagamaan akan dibumikan secara praksis berubah wajahnya menjadi "sesuatu" yang eksklusif, dogmatis, mengedepankan truth claim, dan mudah mengkafirkan orang lain.

Ketahanan budaya kelompok utama (mainstream) secara prinsip mendorong corak beragama berdasarkan pada akhlak yang mulia (personal goodness) dalam menyikapi pluralitas masyarakat, perbedaan madzab, ideologi, dan gerakan keagamaan. Budaya "tidak menyalahkan" dan "saling menjaga" yang diusung civil society ini dalam prinsip tasawuf dikenal dengan istilah "takhalluqu bi akhlaqillah" dan tauhid sebagai "core values" yang mengarahkan pada prinsip persamaan, persaudaraan, dan penghormatan pada pluralisme, Dalam bahasa agama dikenal dengan istilah insan kamil yakni manusia paripurna membuang jauh-jauh tabiat jelek, hate speech, fundamental, dan radikalisme agama.

Ketahanan budaya merupakan upaya mengharmoniskan hubungan agama dengan budaya lokal yang selama ini sudah ada dan mulai diruntuhkan oleh kelompok radikal. Pola relasi antara agama dan budaya diubah sebagai bentuk kritik terhadap pola keberagamaan kelompok Islam ideologis dengan mengedepankan formalitas simbol dan identitas keislaman. Pola ini menjadikan agama ditafsirkan secara teosentris yang bersifat tekstualliteralis, hampa dari ruang dan waktu, sehingga agama menjadi kering karena tidak bersentuhan dengan budaya. Agama dan budaya tidak saling tegur sapa sehingga keduanya berada pada posisi "single entity", dimana agama hanya menjadi ruh tanpa ada raga yakni budaya. Hal ini menjadikan wacana keislaman ketika diimplementasikan secara praksis berubah wajahnya menjadi "sesuatu" yang eksklusif dan dogmatis.

Bentuk ketahanan masyarakat dalam menangkal radikalisme agama dilakukan melalui penguatan civil society dan budaya sebagai cara untuk menjaga keberlangsungan kehidupan sosial baik materaial maupun spiritual secara terus menerus. Bagian penting dari ketahanan masyarakat Solo Raya terletak pada kemampuan memilih nilai-nilai sosialbudaya dan kelembagaan sosial yang mampu mendukung proses kehidupan yang semakin baik dan berkelanjutan. Hal ini berarti nilai sosial-budaya dan lembaga lokal yang sudah ada kemudian dipelihara, diperbaharui, dan dikembangkan secara mandiri oleh warga masyarakat atas kekuatan yang dimiliki. Kemandirian suatu masyarakat terletak pada 
kemampuan memilih dan memutuskan apa yang baik bagi dirinya dan kepentingan lingkungan lebih luas. Menumbuhkan potensi kemandirian masyarakat Solo Raya berarti mendorong proses belajar bersama antara stakeholders untuk melakukan pemetaan terhadap masalah yang dihadapi, mengenali potensi adan sumber yang dimiliki dan mencari peluang untuk mengatasi permasalahan termasuk persoalan radikalisme agama (reaching out).

Terdapat tiga bentuk pensikapan yang dilakukan masyarakat terhadap kelompok radikal yaitu reintegrasi sosial, deradikalisasi, dan demoralisasi. Hal ini sejalan dengan pernyataan Sukimin Kasat Intel Sukoharjo:

'... Ketika ada ancaman ada peristiwa radikalisme agama, upaya kepolisian untuk menggandeng tokoh-tokoh agama untuk menggelorakan tentang perdamaian, kebersamaan, kerukunan, sikap saling menghargai, dan kebhinekaan di tengah masyarakat, Ketika ada orang-orang yang perlu diwaspadai dan dicurigai kita perlu diasah kepekaan masyarakat sekitar..., yang ada di sini memberikan pengertian kepada perangkat negara ketika ada orang-orang yang perlu diwaspadai tolong disampaikan kepada kami kepolisian terdekat. Masyarakat rata-rata apatis, jadi banyaknya kecolongan karena masyarakat kurang peduli, tidak pernah menginformasikan kepada aparat atau kepada kepolisian...'

Pernyataan tersebut mengisyaratkan bahwa Solo Raya merupakan wilayah yang menjadi perhelatan gerakan radikal yang berafiliasi kepada jaringan terorisme lokal, nasional maupun trans-nasional. Berkembangnya gerakan radikal terorisme mengindikasikan ada tiga hal penting, yaitu; pertama, gerakan tersebut menjadi ancaram serius bagi perdamaian, terbuka dan toleran yang selama ini telah berkembang di masyarakat; kedua, gerakan tersebut merupakan ancaman bagi NKRI yang berideologi Pancasila; dan ketiga, gerakan tersebut menjadi ancaman serius bagi aksisten perempuan di ruang publik. Oleh karena itu, community resilience menjadi sebuah agenda penting untuk meredam arus radikal terorisme di Solo Raya. Hal ini dimaksudkan sebagai cara untuk membumikan ajaran agama agar dapat sesuai dan selaras dengan proses modernisasi di tengah masyarakat Solo Raya tanpa harus tercerabut dari akar budayanya,

Hasil diskusi menemukan bahwa model keislaman dengan ketahanan budaya masyarakat dilakukan melalui penguatan simpul-simpul organisasi serta tokoh agama dan masyarakat yang ada di masyarakat Solo Raya. Cara ini dimaksudkan untuk meminimalisir kekerasan yang mengatasnamakan agama dan Tuhan yang telah menjadi sumber ketidakadilakan serta ketidakharmonisan masyarakat. Agama jangan sampai menjadi dan dijadikan institusi yang hanya berkutat pada persoalan teologis, ideologis, retorik, dan tidak mampu berbuat banyak dalam kehidupan sosial, sehingga agama akan kehilangan elan vitalnya dan fungsi sosialnya sebagai penegak keharmonisan sosial, keadilan, kesetaraan dan akomodasi budaya.

Gerakan perlawanan kultural melalui penguatan civil socety dan ketahanan budaya merupakan bentuk respon ketidaksepahamannya terhadap berbagai gerakan radikal yang cenderung menggunakan kekerasan serta simbol-simbol budaya yang tidak sesuai dengan karifan lokal masyarakat Solo Raya. Secara prinsip, tindak kekerasan dengan menggunakan label agama adalah bentuk dan pengingkaran terhadap agama itu sendiri, karena dapat mereduksi dan merusak nilai-nilai universal yang dikandung agama. Penguatan civil society dan ketahanan budaya perlu diwujudkan dengan mengedepankan al-Islam shalih likuli zaman wa makan agar agama bisa terus berkembang dengan sifatnya yang akomodatif dan 
menggandeng budaya lokal dimana ia hadir. Sinergitas antara agama dan budaya lokal akan melahirkan Islam Indonesia bisa lebih kaya karena sarat dengan nilai-nilai luhur budaya lokal yang penuh kearifan, santun dan toleran, seperti yang selama ini menjadi pandangan dunia (worldview) masyarakat Solo Raya, Dengan menghadirkan Islam yang ramah dan toleran, maka dengan sendirinya dapat dijadikan counter concept terhadap gerakan radikal dan sekaligus sebagai bentuk deradikalisasi wacana yang bisa mendorong tampilnya agama yang humanis dan universal serta mampu mengakomodir nilai atau kekuatan budaya local.

\section{KESIMPULAN}

Terpaan beberapa peristiwa kekerasan yang berujung pada tindakan teror yang berakar dari faham radikal di wilayah Solo Raya telah menimbulkan berbagai macam respons dan melahirkan adanya kesadaran bersama masyarakat untuk melakukan tindakan nyata dengan membangun sebuah ketahanan komunitas (community resiliency). Melalui teknik diskusi grup terfokus (focus group discussion) di empat kabupaten/ kota yang melibatkan 56 orang dari berbagai latar belakang dan profesi, penelitian ini menjawab pertanyaaan penelitian dengan menghasilkan beberapa temuan lapangan mengenai bentuk ketahanan yang dimiliki dan dibangun oleh masyarakat Solo Raya.

Ketahanan masyarakat Solo Raya tercermin dari cara pandang kritis masyarakat terhadap beberapa peristiwa kekerasan dan teror yang terjadi di Surakarta, Sukoharjo, Karanganyar dan Sragen. Mereka berpendapat bahwa tindakan tersebut tidak sesuai dengan nilai dan ajaran agama yang mereka yakini, dimana agama selalu mengajarkan perdamaian, tidak merusak, menghargai perbedaan dan menebarkan cinta kasih kepada sesama tanpa memandang latar belakang sosial, agama, dan keyakinan. Selanjutnya, masyarakat merasa yakin dan penuh percaya diri bahwa mereka mampu untuk menghadapinya dengan kekuatan yang dimiliki dengan saling berkomunikasi dan kordinasi serta saling menguatkan diantara kelompok dan organisasi yang ada.

Aspek lain yang menjadi temuan dalam penelitian ini adalah terjalinnya kemitraan politik yang harmonis antara organisasi sosial kemasyarakatan, pemuda, wanita, dan keagamaan dengan pemerintah daerah, pihak aparat kepolisian dan TNI. Kemitraan tersebut diwujudkan dalam bentuk komunikasi dan kordinasi secara rutin dan insidental serta penyelenggaraan kegiatan bersama. Masyarakat melakukan tindakan nyata dalam melakukan pencegahan radikal terorisme melalui kegiatan pengajian, seminar, dan dialog lintas golongan dan agama. Kreatifitas masyarakat juga dibanguan melalui berbagai kegiatan kesenian seperti pentas wayang, kesenian hadrah, dan pameran lukisan sebagai gerakan kultural membendung faham radikal.

Penguatan peran civil society sebagai counter terhadap gerakan dan wacana radikalisme agama, yang dilakukan oleh masyarakat Solo Raya merupakan kompetensi komunitas yang sudah diberdayakan dalam rangka mempersatukan simpul-simpul kekuatan untuk mengampanyekan konsep Islam rahmatan lil'alamin, sebagai agama yang ramah dan damai.

Masyarakat Solo Raya memiliki kegiatan budaya yang dimanfaatkan untuk membangun kesadaran pluralisme dan keindonesiaan. Menanamkan pemahaman bahwa radikalisme merupakan faham yang tidak cocok dengan keyakinan masyarakat, karena setiap agama mengajarkan kasih sayang dan cinta kasih sejak lingkup sosial terkecil yaitu keluarga. Pengembangan nilai-nilai agama dan kebangsaan yang ramah sebagai social 
capital untuk membentuk karakter dan identitas bangsa yang santun, terbuka dan saling menghormati sesama serta menghindarkan dari pemahaman keagamaan yang eksklusif, intoleran dan radikal.

Temuan ini memperkuat teori community resilence yang disampaikan oleh Norris (2008) yang mengatakan bahwa ketahanan masyarakat merupakan sebuah proses adaptasi terhadap datangnya bahaya atau bencana dengan membangun kesadaran pluralitas, sinergitas antar lembaga, komunikasi budaya dan kemitraan strategis.

\section{DAFTAR PUSTAKA}

Acket, Sylvain, et,al,, 2011, Measuring and validating social cohesion: a bottom-up approach, Luxembourg: CEPS Instead Working Press

Aijudin, Anas, 2008, Laporan Penelitian Transformasi Sosial Gerakan Keagamaan di Surakarta, Puslitbang Kemenag; Semarang,

Ainsworth, M. D. S., 1978. Patterns of attachment: A psychological study of the strange situation. Lawrence Erlbaum

Asrori, M. dan Ali, M., 2015, Psikologi Remaja: Perkembangan Peserta Didik. Jakarta: Bumi Aksara.

Azra, Azyumardi, 1993, 1993. Esai-esai Intelektual Muslim dan Pendidikan Islam, Jakarta: Logos Wacana Ilmu

Bandura, A., 1977, 'Self-efficacy: Toward a unifying theory of behavioral change'. Psychological Review. 84(2). 191-215

Baso, Ahmad. 2015. Agama NU Untuk NKRI, Jakarta; Pustaka Afid

Bowlby, J.,1982. Attachment and loss: Vol. 1, Attachment (2nd ed.). New York: Basic Books.

Creswell, John W. 2013, Researcrh Design : Qualitative, Quantitatif, \& Mixed Methods Approaches, London : Sage Publications.

Faqih, Mansour, 2008, Analisis Gender dan Transformasi Sosial, Yogyakarta: Insist Press,

Gunderson, Lance H. Craig Reece Allen, C. S. Holling, 2012, Foundations of Ecological Resilience. Washington, D.C.: Island Press

Hasanah, Nur, 2018, Upaya Pemerintah Indonesia dalam Mengatasi Terorisme pada Masa Pemerintahan Joko Widodo Tahun 2014-2019, eJournal Ilmu Hubungan Internasional, Vo,6, Nomor 3, 2018: 881-892,

Ellis, B Heidi \& Saida Abdi, 2017, 'Building Community Resilience to Violent Extremism Through Genuine Partnerships', American Psychologist, Vol, 72, No, 3, 289-300, American Psychological Association

Idris, Irfan, 2017, Deradikalisasi; Kebijakan, Strategidan Program Penanggulangan Terorisme, Yogyakarta: Cahaya Insani

International Federation of Red Cross and Red Crescent Societies,, 2014, IFRC Framework for Community Resilience, Genewa: IFRC,

Jafar, Tiara Firdaus, dkk,, 2019, Ketahanan Nasional Menghadapi Ancaman Lone Wolf Terrorism di Jawa Barat, Jurnal Ketahanan Nasional, Vo, 25 No,1 April 2019, h,73-9,

Jenson, Jane, 2010, Defining and Measuring Social Cohesion, Commonwealth Secretariat and United Nations Research Institute for Social Development: United Kingdom.

Juergensmeyer, Mark, 2001, Terror in the Mind of God, The Global Rise of Religious Violence Berkeley \& L,A: University of California Press. 
Karim, A., Adeni, A., Fitri, F., Fitri, A., Hilmi, M., Fabriar, S., \& Rachmawati, F. (2021). Pemetaan untuk strategi dakwah di kota semarang menggunakan pendekatan data mining. Jurnal Dakwah Risalah, 32(1). doi:http://dx.doi.org/10.24014/jdr.v32i1.12549.

Kindt, Michael T, 2006, Building Population Resilience to Terror Attacks Unlearned Lessons from Military and Civilian Experience, Counterproliferation Paper No, 36 USAF, Alabama: Air University Maxwell Air Force Base

Larsen, Christian Albrekt, 2014, Social cohesion: Definition, measurement and developments, Aalborg Universititet,

Masten, A, S,, 2001, 'Ordinary magic: Resilience processes in development', American Psychologist, Vol,56, 227-238,

Masten, A, S,2007, 'Resilience in developing systems: Progress and promise as the fourth waves rises', Development and Psychopatology, 19, 921- 930, doi: 10,1017/S0954579407000442

Mibtadin, 2017. Gerakan Sosial Masyarakat Sipil. Studi Gerakan Sosial LKiS, Fahmina, dan The Wahid Institute. Yogyakarta: UIN Sunan Kalijaga. Unpublished dissertation

Muhyiddin, Asep, 2002, Dakwah dalam Perspektif Al-Qur'an, Pustaka Setia: Bandung

Mu'in M,, Abdul, dkk., 2007, Pendidikan Pesantren dan Potensi Radikalisme, Jakarta: CV, Prasasti,

Mushtaq, Rehan 2009, De-Radicalization Of Muslim Communities In The UK, MA Thesis, Unpublished, California: Naval Postgraduate School.

Musyafak, N, 2017, 'Bersinergi untuk Deradikalisasi' dalam Deradikalisasi NKRI; Pesan Damai dari Jawa Tengah, Semarang; CV Rafi Pratama.

Musyafak, N dan Lulu Choirun Nisa, 2019, Resiliensi Masyarakat Melawan Radikalisme; Aksi Damai dalam Konflik Agama, Semarang; Lawwana.

Norris, Fran H.et al., 2008, 'Community Resilience as a Metaphor, Theory, Set of Capacities, and Strategy for Disaster', dalam American Journal of Community Psychology, April 2008, DOI: 10.1007/s10464-007-9156-6

Ong Hok Ham 1998, Kapok Jadi Non Pribumi, Warga Tionghoa Mencari Keadilan, Bandung: Zaman,

Purwawidada, Fajar, 2014, Jaringan Baru Teroris Solo, Jakarta: KPG.

Reivich, K, dan Shatte, A, 2002, The Resiliency Factor :7 Keys to Finding Your Inner Strength and Overcoming Life's Hurdles, New York: Three Rivers Press.

Sefriyono dan Mukhibat, 2018, Preventing Religious Radicalism Based on Local Wisdom: Interrelation of Tarekat, Adat, and Local Authority in Padang Pariaman, West Sumatera, Indonesia, Sosiohumanika: Jurnal Pendidikan Sains Sosial dan Kemanusiaan, Vol, 11 (1), Mei 2018: 1-18

Solichun, 2018, Peran Organisasi Pemuda Dalam Menangkal Radikalisme (Studi pada GP Ansor Kota Surabaya Periode 2017-2021), Tesis, 2018: 1-118

Speckhard, A, 2005, Civil Society's Response to Mass Terrorism: Building Resilience, In R, Gunaratna (Ed,), Combating Terrorism: Military and Non Military Strategies, Singapore: Eastern Universities Press.

Sugiyono, 2014, Metodologi Penelitian Kombinasi (Mixed Method), Bandung: Alfabeta 
Weine, Stevan, and Osman Ahmed, 2012, "Building Resilience to Violent Extremism Among Somali-Americans in Minneapolis-St, Paul," Final Report to Human Factors/Behavioral Sciences Division, Science and Technology Directorate, U,S, Department of Homeland Security, College Park, MD: START

Yusup, Yasin, 2016, 'Resiliensi Komunitas di Kawasan Rawan Bencana Gunungapi Merapi dalam Perspektif Konstruksi Ruang-Waktu', Disertasi, Tidak dipublikasikan, Bandung: Institut Teknologi Bandung 